[Chem. Pharm. Bull.

35( 5 ) 1991-1997(1987)

\title{
New Heterobifunctional Cross-Linking Reagents for Protein Conjugation, $N$-(Bromoacetamido-n-alkanoyloxy)succinimides
}

\author{
Kiyoshi Zaitsu, ${ }^{a}$ Mikio Ohnishi, ${ }^{b}$ Hiroyuki Hosoya,,${ }^{a}$ \\ Hiroyuki Sugimoto, ${ }^{b}$ and Yosuke OhKura, ${ }^{* a}$ \\ Faculty of Pharmaceutical Sciences, Kyushu University 62, ${ }^{a}$ Maidashi Higashi-ku, \\ Fukuoka 812, Japan and Wakunaga Pharmaceutical Co., Ltd., ${ }^{b}$ \\ Koda-cho, Takata-gun, Hiroshima 729-64, Japan
}

(Received October 3, 1986)

\begin{abstract}
Five heterobifunctional reagents, $N$-(bromoacetamido- $n$-alkanoyloxy)succinimides having a glycine or ( () -amino acid $(\beta$-alanine, $\gamma$-aminobutyric acid, $\delta$-aminovaleric acid or $\varepsilon$-aminocaproic acid) residue, were synthesized. Bromoacetamido- $n$-alkanoyl groups could be introduced into horseradish peroxidase and hen egg-white lysozyme and its reduced and $S$-3-(trimethylated amino)propylated product by using the reagents. The number of bromoacetamido- $n$-alkanoyl groups introduced into the proteins could be successfully estimated from the amount of glycine or (1)-amino acid (non-protein amino acid) produced from the introduced groups by acid hydrolysis. $N$ - $(\beta$-Bromoacetamido- $n$-propionoyloxy)succinimide, one of the reagents, was examined as a reagent for the preparation of horseradish peroxidase-insulin conjugate. A single $\beta$-bromoacetamido- $n$-propionoyl group was first introduced into $\mathrm{Gly}^{\mathrm{A} 1}, \mathrm{Phe}^{\mathrm{B} 1}$-dicitraconylinsulin through the $\varepsilon$ amino group of its Lysine ${ }^{\mathrm{B} 29}$ residue and the product was subjected to decitraconylation with dilute acetic acid to obtain Lys ${ }^{\mathrm{B} 29}$-( $\beta$-bromoacetamido- $n$-propionoyl $)$ insulin. The insulin was reacted with thiolated horseradish peroxidase to give peroxidase-insulin conjugate (molar ratio of $1: 1$ ).
\end{abstract}

Keywords heterobifunctional cross-linking reagent; protein conjugation; $N$-(bromoacetamido- $n$-alkanoyloxy)succinimide; $\omega$-amino acid; amino acid analysis; enzyme label; horseradish peroxidase; insulin

Bifunctional cross-linking reagents are essential for the preparation of protein-protein conjugates, protein-low molecular compound conjugates, ligand-linked solid matrices and immobilized enzymes, which have been used in biological, physiological, pharmacological and analytical researches. Among these reagents, heterobifunctional reagents are especially useful to bind either the same or different proteins with each other without the undesirable linking inherent in the use of homobifunctional reagents. ${ }^{1,2)}$ A currently available heterobifunctional reagent, $N$-succinimidyl-3-(2-pyridyldithio)propionate (SPDP) ${ }^{3)}$ has been used in the preparation of enzyme-labeled Fab' of immunoglobulin $\mathrm{G}$ (IgG), ${ }^{4,5)}$ enzyme-labeled deoxyribonucleic acid (DNA), ${ }^{6)}$ calmodulin-linked thiol-Sepharose ${ }^{7)}$ and antibody-linked liposomes. ${ }^{8)}$ Combinations of functional groups in other heterobifunctional cross-linking reagents were maleimidyl and succinimidyl groups, ${ }^{8,9)}$ and chloroformyl and bromoacetyl groups. ${ }^{10)}$

This paper describes the synthesis and application of a new series of heterobifunctional cross-linking reagents, $N$-(bromoacetamido- $n$-alkanoyloxy)succinimides (II $(n)$, Chart 1$)$. The reagents can react with primary amino group(s) of a protein at the $N$-succinimidyl ester side to yield the protein carrying a bromoacetamido- $n$-alkanoyl group(s), and then with sulfhydryl group(s) of another protein through the introduced bromoacetyl group(s) to give a protein-protein conjugate. These reagents have a glycine residue (II(1)) or one of the $\omega$-amino acid (II(2)-II(5); $\beta$-alanine, ${ }^{11)} \gamma$-aminobutyric acid, $\delta$-aminovaleric acid and $\varepsilon$-aminocaproic acid, respectively) residues (Chart 1). This enabled us to develop a powerful method for the estimation of the number of bromoacetamido- $n$-alkanovl group(s) introduced into protein. 
and the molar ratio of protein to protein in a conjugate prepared with $\mathrm{II}(n)$ except for II( $(1)$.

To verify the utility of the reagents, we investigated the introduction of bromoacetamido$n$-alkanoyl groups of II $(n)$ into horseradish peroxidase (HRP), hen egg-white lysozyme and its reduced and $S$-3-(trimethylated amino)propylated product (RT-lysozyme), ${ }^{12)}$ and we also prepared an HRP-insulin conjugate using II(2) as an example of protein-protein conjugate preparation.

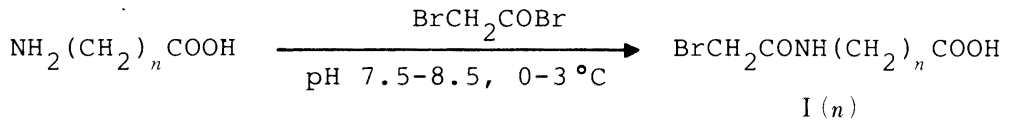

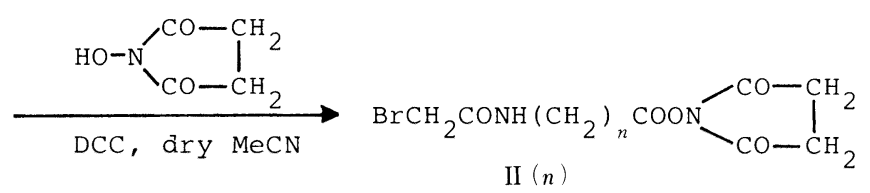

$$
\begin{aligned}
& n=1,2,3,4 \text { and } 5
\end{aligned}
$$

Chart 1. Synthesis of $\mathrm{II}(n)$

II(1), $N$-(bromoacetamidoacetoxy)succinimide; II(2), $N$-( $\beta$-bromoacetamido- $n$-propionoyloxy)succinimide; II(3), $N$ - $(\gamma$-bromoacetamido- $n$-butyryloxy)succinimide; II(4), $N$-( $\delta$ bromoacetamido- $n$-valeroyloxy)succinimide; II(5), $N$-( $\varepsilon$-bromoacetamido- $n$-caproyloxy)succinimide.

\section{Experimental}

Materials and Apparatus_-Deionized water was used, which was filtered through a Milli-QII (Japan Millipore Ltd., Tokyo, Japan) before use. Diisopropyl ether (iso- $\operatorname{Pr}_{2} \mathrm{O}$ ) was passed through a column of neutral alumina AG 7 (100-200 mesh; Bio-Rad, Richmond, U.S.A.) to remove peroxide, which was checked with Peroxide Test (Japan Merck, Tokyo, Japan). Aqueous urea was passed through an Amberlite MB 3 (mixed resin 20-50 mesh; Bio-Rad) column. HRP (285 purpurogallin units/mg, type VI; Sigma, St. Louis, U.S.A.). Hen egg-white lysozyme and RTlysozyme ${ }^{12)}$ (both from Seikagaku Kogyo, Tokyo, Japan) were used. Gly ${ }^{A 1}$,Phe ${ }^{B 1}$-Dicitraconylinsulin (porcine) was prepared as described previously. ${ }^{13)}$ All other chemicals were of reagent grade.

Melting points were measured on a Yanagimoto micromelting point apparatus. Absorbances were measured with a Hitachi 150-20 spectrophotometer in semimicro-quartz cells (10-mm optical path length, $1 \mathrm{ml})$. Electron impact mass spectra were taken with a JEOL JMS-DX300 mass spectrometer. Fluorescence intensities in the microassay of HRP activity ${ }^{14)}$ were measured with a Hitachi MPF-4 spectrofluorimeter in semimicro-quartz cells (10$\mathrm{mm}$ width parallel to the excitation beam, 3-mm length parallel to the emission beam, $1 \mathrm{ml}$ ).

Chromatographic Conditions-Thin layer chromatography (TLC) was performed on Silica gel F-254 precoated aluminum-backed sheets (Japan Merck) with $\mathrm{CHCl}_{3}-\mathrm{MeOH}(19: 1, \mathrm{v} / \mathrm{v}$; solvent A) and $(4: 1$, v/v; solvent B) as developing solvents. Fractions on the plates were detected by fluorescence quenching under ultraviolet light or by the use of ninhydrin ( $1 \%$ in butanol) spray followed by heating at $50{ }^{\circ} \mathrm{C}$ for $1 \mathrm{~min}$ after successive treatments with ammonia vapor and $\mathrm{AcOH}$ vapor. $\mathrm{N}$-Hydroxysuccinimide esters were detected by the ferric chloride method. ${ }^{15}$ ).

Adsorption column chromatography was carried out on a Silica gel 60 (Japan Merck) column $(400 \times 15 \mathrm{~mm}$ i.d.) with stepwise elution using $100 \mathrm{ml}$ of $\mathrm{CHCl}_{3}$ and $200 \mathrm{ml}$ each of $\mathrm{CHCl}_{3}$ solutions containing $0.5,1,2$, and $3 \%(\mathrm{v} / \mathrm{v})$ $\mathrm{MeOH}$.

Anion-exchange high-performance liquid chromatography (HPLC) was carried out on a TSK gel DEAE-2SW column $(300 \times 7.8 \mathrm{~mm}$ i.d.; Toyo Soda, Tokyo, Japan) with a Hitachi 655 liquid chromatograph equipped with a 655 proportioning valve pump for gradient elution, a $650-60$ recording processor, a Rheodyne 7125 syringe-loading sample injector valve (100- $\mu$ l loop) and a Toyo Soda UV-8 model II spectrophotomonitor operated at $278 \mathrm{~nm}$. Elution with an $\mathrm{NaCl}$ concentration gradient during $40 \mathrm{~min}$ was done at a flow rate of $1.4 \mathrm{ml} / \mathrm{min}$ with eluant $\mathrm{A}$ $(0.05 \mathrm{M} \mathrm{Na}-\mathrm{K}$ phosphate buffer ( $\mathrm{pH} 7.0)$ containing $4 \mathrm{M}$ urea) and eluant B (eluant A containing $0.5 \mathrm{M} \mathrm{NaCl}$ ). The $\mathrm{NaCl}$ gradient was as follows: the initial eluant contained $90 \%$ of eluant $\mathrm{A}$ and $10 \%$ of eluant $\mathrm{B}$. The content of eluant $\mathrm{B}$ was increased to $30 \%$ linearly during $20 \mathrm{~min}$ and to $100 \%$ linearly during another $20 \mathrm{~min}$. The used column was regenerated by passing eluant $\mathrm{B}$ for $20 \mathrm{~min}$ and then the initial eluant for $20 \mathrm{~min}$. Chromatogram peaks were identified by the 1 -fluoro-2,4-dinitro-benzene method. ${ }^{13,16)}$

Gel-permeation HPLC was done on a TSK gel G3000SW column $(600 \times 7.5 \mathrm{~mm}$ i.d.; Toyo Soda) with a Waters 
M-45 liquid chromatograph equipped with a Rheodyne 7125 syringe-loading sample injector valve (200- $\mu$ loop) and a Waters 440 absorbance detector operated at 254 and $405 \mathrm{~nm}$. The mobile phase was $0.05 \mathrm{M} \mathrm{Na}$ phosphate buffer (pH 7.0) containing $0.15 \mathrm{M} \mathrm{NaCl}$, and the flow rate was $0.7 \mathrm{ml} / \mathrm{min}$.

Amino Acid Analysis — Performed on a Hitachi 835 amino acid analyzer after hydrolysis of protein samples in $6 \mathrm{M} \mathrm{HCl}$ in vacuo at $110^{\circ} \mathrm{C}$ for $24 \mathrm{~h}$, using a column $(150 \times 4 \mathrm{~mm}$ i.d.) packed with a Hitachi 2619 custom ionexchanger resin with the sodium citrate buffer system as the mobile phase. The column temperature was $53^{\circ} \mathrm{C}$. The stepwise elution of amino acids was carried out as described in the handling manual ${ }^{17}$ except that the concentrations of benzyl alcohol in eluants III and IV described in the manual ( 0 and $5 \%(\mathrm{v} / \mathrm{v})$, respectively) were changed to 5 and $10 \%(\mathrm{v} / \mathrm{v})$, respectively.

Determination of Bromoacetamido-n-alkanoyl Groups Introduced into Proteins - The number of bromoacetamido-n-alkanoyl groups $\left(\mathrm{BrCH}_{2} \mathrm{CONH}\left(\mathrm{CH}_{2}\right)_{n} \mathrm{CO}-, n=1,2,3,4\right.$ or 5) incorporated into proteins was determined from the amount of glycine (calculated by subtracting the amount of glycine in intact protein), $\beta$-alanine, $i$-aminobutyric acid, $\delta$-aminovaleric acid or $\varepsilon$-aminocaproic acid, respectively; the chromatogram peaks of these $(1)-$ amino acids (non-protein amino acids) were observed in that order between the peaks for tyrosine and phenylalanine, phenylalanine and lysine, lysine and ammonia, and histidine and arginine, respectively. When the peak area obtained with glycine was taken as 100 , those with $\beta$-alanine, $;$-aminobutyric acid, $\delta$-aminovaleric acid and $\varepsilon$-aminocaproic acid were $51.2,98.1,81.1$ and 60.1 , respectively.

Synthesis of $\boldsymbol{N}$-(Bromoacetamido- $\boldsymbol{n}$-alkanoyloxy)succinimides (II(n)) via Bromoacetamido-n-alkylcarboxylic Acids $(\mathbf{I}(\boldsymbol{n}))-\mathrm{I}(1)-\mathrm{I}(3)$ and $\mathrm{I}(5)$ (Chart 1) were synthesized by the previous method. ${ }^{18)} \mathrm{I}(4)$ (Chart 1) was prepared by bromoacetylation of $\delta$-aminovaleric acid with bromoacetyl bromide in the same way as reported previously, with some modifications. ${ }^{18)}$ The reaction was carried out at $\mathrm{pH} 7.5-8.5$ in an ice-water bath. I(1) was obtained in sufficiently pure form. $\mathrm{I}(2)$ - $\mathrm{I}(5)$ were purified by adsorption chromatography. Fractions ( $40 \mathrm{ml}$ each) containing I(2) - I(5) were collected, checked by TLC ( $R f$ values (solvent A, solvent B): I(2) $(0.10,0.49)$; I(3) $(0.11,0.57)$; I(4) $(0.13,0.63) ; \mathrm{I}(5)(0.18,0.66))$, concentrated to dryness and recrystallized from tetrahydrofuran $(\mathrm{THF})$-iso- $\mathrm{Pr}_{2} \mathrm{O}$. $\mathrm{The}^{-}$ melting points of $\mathrm{I}(1)-\mathrm{I}(3)$ were in agreement with reported data. ${ }^{18)}$ That of $\mathrm{I}(5)$ was $78-79 \mathrm{C}$, though it was reported to be $69-70 \mathrm{C}^{18)} \mathrm{I}(4)(\mathrm{mp} 77-78 \mathrm{C}$, colorless powder, yield $20 \%$ ) was characterized by the following data. Anal. Calcd for $\mathrm{C}_{7} \mathrm{H}_{12} \mathrm{BrNO}_{3}$ : C, 35.31; H, 5.08; N, 5.88. Found: C, 35.03; H, 5.03; N, 5.86. Mass spectrum (MS) $m / z: 238\left(\mathbf{M}^{+} \mathrm{H}\right), 240\left(\mathbf{M}^{+} \mathrm{H}+2\right)$.

$\mathrm{I}(n)(1.0 \mathrm{mmol})$ and $N$-hydroxysuccinimide $(1.0 \mathrm{mmol})$ were dissolved in $15 \mathrm{ml}$ of dry MeCN , and then $1.0 \mathrm{mmol}$ of $N, N^{\prime}$-dicyclohexylcarbodiimide (DCC) in $5 \mathrm{ml}$ of dry MeCN was added. The mixture was stirred under protection from moisture at $4 \mathrm{C}$ overnight. The resulting precipitates were filtered off, the filtrate was concentrated to dryness, and the residue was recrystallized from THF-iso- $\operatorname{Pr}_{2} \mathrm{O}$ to give $\mathrm{II}(n)$ (all colorless needles). The melting points, yields, elemental analyses and MS data are summarized in Table I.

Introduction of Bromoacetamido-n-alkanoyl Groups into HRP - HRP $(62.5 \mathrm{nmol}, 2.5 \mathrm{mg})$ was dissolved in $500 \mu \mathrm{l}$ of $0.1 \mathrm{M} \mathrm{Na}$ phosphate buffer ( $\mathrm{pH} 7.5$ ), and a 10 to 100 -fold molar excess of $\mathrm{II}(n)$ in $100 \mu \mathrm{l}$ of $\mathrm{MeCN}$ was added under stirring. The mixture was kept at $23 \mathrm{C}$ for $1 \mathrm{~h}$, dialyzed against 11 of water ( 7 times) at $4 \mathrm{C}$ and lyophilized. The number of bromoacetamido- $n$-alkanoyl groups introduced into HRP was calculated from the amino acid analysis data.

TABLE I. Data for II $(n)$

\begin{tabular}{|c|c|c|c|c|c|c|c|c|c|c|}
\hline \multirow{2}{*}{$\begin{array}{l}\text { Com- } \\
\text { pound }^{a}\end{array}$} & \multirow{2}{*}{$\begin{array}{l}m p^{h)} \\
(\mathrm{C})\end{array}$} & \multirow{2}{*}{$\begin{array}{l}\text { Yield } \\
(\%)\end{array}$} & \multirow{2}{*}{$\begin{array}{l}\text { Formula } \\
\text { Molecular } \\
\text { weight }\end{array}$} & \multirow{2}{*}{\multicolumn{3}{|c|}{$\begin{array}{c}\text { Elemental analysis } \\
\text { Calcd (Found) } \\
(\%)\end{array}$}} & \multirow{2}{*}{\multicolumn{2}{|c|}{$\begin{array}{l}\text { MS peak } \\
\quad(m / z)\end{array}$}} & \multicolumn{2}{|c|}{$\begin{array}{l}R f \text { in TLC } \\
\text { Solvent }{ }^{d)}\end{array}$} \\
\hline & & & & & & & & & A & $\mathrm{B}$ \\
\hline $\mathrm{II}(1)$ & $119-121$ & 76.1 & $\begin{array}{c}\mathrm{C}_{8} \mathrm{H}_{9} \mathrm{BrN}_{2} \mathrm{O}_{5} \\
293.1\end{array}$ & $\begin{array}{r}32.78 \\
(32.69\end{array}$ & $\begin{array}{l}3.09 \\
3.14\end{array}$ & $\begin{array}{l}9.55 \\
9.44)\end{array}$ & $293\left(\mathrm{M}^{+} \mathrm{H}\right)$ & $295\left(\mathrm{M}^{+} \mathrm{H}+2\right)$ & 0.21 & 0.73 \\
\hline $\mathrm{II}(2)$ & $104-106$ & 50.6 & $\begin{array}{c}\mathrm{C}_{9} \mathrm{H}_{11} \mathrm{BrN}_{2} \mathrm{O}_{5} \\
307.1\end{array}$ & $\begin{array}{r}35.19 \\
(35.32\end{array}$ & $\begin{array}{l}3.61 \\
3.66\end{array}$ & $\begin{array}{l}9.12 \\
9.32)\end{array}$ & $307\left(\mathrm{M}^{+} \mathrm{H}\right)$ & $309\left(\mathrm{M}^{+} \mathrm{H}+2\right)$ & 0.25 & 0.73 \\
\hline $\mathrm{II}(3)$ & $98-100$ & 53.3 & $\begin{array}{c}\mathrm{C}_{10} \mathrm{H}_{13} \mathrm{BrN}_{2} \mathrm{O}_{5} \\
321.1\end{array}$ & $\begin{array}{r}37.40 \\
(37.87\end{array}$ & $\begin{array}{l}4.08 \\
4.27\end{array}$ & $\begin{array}{l}8.72 \\
8.70)\end{array}$ & $321\left(\mathrm{M}^{+} \mathrm{H}\right)$ & $323\left(\mathrm{M}^{+} \mathrm{H}+2\right)$ & 0.25 & 0.73 \\
\hline $\mathrm{II}(4)$ & $78-79$ & 52.4 & $\begin{array}{c}\mathrm{C}_{11} \mathrm{H}_{15} \mathrm{BrN}_{2} \mathrm{O}_{5} \\
335.2\end{array}$ & $\begin{array}{r}39.42 \\
(39.39\end{array}$ & $\begin{array}{l}4.51 \\
4.51\end{array}$ & $\begin{array}{l}8.35 \\
8.42)\end{array}$ & $\begin{array}{l}334\left(\mathrm{M}^{+}\right) \\
336\left(\mathrm{M}^{+}+2\right)\end{array}$ & $\begin{array}{l}335\left(\mathrm{M}^{+} \mathrm{H}\right) \\
337\left(\mathrm{M}^{+} \mathrm{H}+2\right)\end{array}$ & 0.27 & 0.73 \\
\hline $\mathrm{II}(5)$ & $89-90$ & 69.8 & $\begin{array}{c}\mathrm{C}_{12} \mathrm{H}_{17} \mathrm{BrN}_{2} \mathrm{O}_{5} \\
349.2\end{array}$ & $\begin{array}{r}41.28 \\
(41.08\end{array}$ & $\begin{array}{l}4.90 \\
5.03\end{array}$ & $\begin{array}{l}8.02 \\
7.91)\end{array}$ & $\begin{array}{l}348\left(\mathrm{M}^{+}\right) \\
350\left(\mathrm{M}^{+}+2\right)\end{array}$ & $\begin{array}{l}349\left(\mathrm{M}^{+} \mathrm{H}\right) \\
351\left(\mathrm{M}^{+} \mathrm{H}+2\right)\end{array}$ & 0.35 & 0.76 \\
\hline
\end{tabular}

a) Stable for 3 months when kept dry under protection from light. b) Uncorrected. c) Assigned by analogy with the peak for $\mathrm{M}^{+} \mathrm{H}+2$ of II(1) (found, $m / z 294.9777$; calcd for $\mathrm{C}_{8} \mathrm{H}_{10}{ }^{81} \mathrm{BrN}_{2} \mathrm{O}_{5}, m / z 294.9753$ ) in the high-resolution MS. $d$ ) See the experimental section. 
Introduction of Bromoacetamido-n-alkanoyl Group into Lysozyme and RT-Lysozyme _ Lysozyme or RTlysozyme $(22.5 \mathrm{nmol} ; 320$ and $350 \mu \mathrm{g}$, respectively) was dissolved in $360 \mu \mathrm{l}$ of $0.1 \mathrm{M} \mathrm{Na}$ phosphate buffer ( $\mathrm{pH} 7.5)$ and a 10 to 100 -fold molar excess of $\mathrm{II}(n)$ in $20 \mu \mathrm{l}$ of dry $\mathrm{MeCN}$ was added under stirring. The mixture was maintained at $23{ }^{\circ} \mathrm{C}$ for $1 \mathrm{~h}$, dialyzed against 11 of water $\left(5-7\right.$ times) at $4{ }^{\circ} \mathrm{C}$ and lyophilized. The number of introduced bromoacetamido- $n$-alkanoyl groups was calculated from the amino acid analysis data.

Preparation of $\mathbf{L y s}^{\mathrm{B} 29}$-( $\boldsymbol{\beta}$-Bromoacetamido- $\boldsymbol{n}$-propionoyl)insulin (BAP-insulin)-A solution of II(2) $(17 \mu \mathrm{mol}$, $5.2 \mathrm{mg})$ in $100 \mu \mathrm{l}$ of $\mathrm{MeCN}$ was added to a solution of $\mathrm{Gly}^{\mathrm{A} 1}, \mathrm{Phe}^{\mathrm{B} 1}$-dicitraconylinsulin $(0.17 \mu \mathrm{mol}, 1 \mathrm{mg})$ in $1.0 \mathrm{ml}$ of $0.1 \mathrm{M} \mathrm{Na}$ phosphate buffer $\left(\mathrm{pH} 7.5\right.$ ) containing $0.1 \mathrm{M} \mathrm{NaCl}$ at $30^{\circ} \mathrm{C}$ under stirring, and stirring was continued for $1 \mathrm{~h}$. The resulting mixture containing $\mathrm{Gly}^{\mathrm{A} 1}, \mathrm{Phe}^{\mathrm{B} 1}$-dicitraconyl-BAP-insulin was dialyzed against 11 of $1 \mathrm{M} \mathrm{AcOH}(\mathrm{pH}$ 2.5) (3 times) at $4{ }^{\circ} \mathrm{C}$. The dialyzate was allowed to stand at $30^{\circ} \mathrm{C}$ for $20 \mathrm{~h}$ to decitraconylate, dialyzed against $1 \mathrm{l}$ of water ( 3 times) at $4{ }^{\circ} \mathrm{C}$ and lyophilized. The resulting powder was dissolved in $200 \mu$ of $0.1 \mathrm{M}$ Na phosphate buffer ( $\mathrm{pH}$ $7.0)$ and subjected to anion-exchange HPLC. The BAP-insulin fraction was dialyzed against 11 of water (4 times) at $4 \mathrm{C}$ and lyophilized. The colorless powder $(0.5 \mathrm{mg})$ thus obtained was stored at $-20 \mathrm{C}$. The molar ratio of BAP group to insulin moiety was estimated by the amino acid analysis data.

Preparation of $\mathrm{Gly}^{\mathrm{A} 1}$, $\mathrm{Phe}^{\mathrm{B} 1}$-Dicitraconyl-BAP-insulin and $\mathbf{P h e}^{\mathrm{B} 1}$-Citraconyl-BAP-insulin $-\mathrm{Gly}^{\mathrm{A} 1}, \mathrm{Phe}^{\mathrm{B} 1}-\mathrm{Di}^{\mathrm{i}}$ citraconylinsulin $(0.85 \mu \mathrm{mol}, 5 \mathrm{mg})$ was reacted with II (2) $(85 \mu \mathrm{mol}, 26 \mathrm{mg})$ in the same way as described above using 5 volumes of the solvents. The resulting mixture was dialyzed against 11 of water ( 3 times) at $4 \mathrm{C}$ and lyophilized. The lyophilizate was dissolved in $300 \mu \mathrm{l}$ of $0.1 \mathrm{~m} \mathrm{AcOH}$. This solution was allowed to stand at $4 \mathrm{C}$ for $10 \mathrm{~h}$, then $3 \mathrm{ml}$ of water was added, and the mixture was neutralized with $2.5 \mathrm{M} \mathrm{NaOH}$. The neutralized mixture was dialyzed against 11 of water ( 3 times) at $4{ }^{\circ} \mathrm{C}$ and lyophilized again. The resulting powder was dissolved in $400 \mu$ lof eluant A. A portion $(40 \mu \mathrm{l})$ of the solution was subjected to anion-exchange HPLC. The eluates corresponding to the peaks of $\mathrm{Gly}^{\mathrm{A} 1}$,Phe ${ }^{\mathrm{B} 1}$-dicitraconyl-BAP-insulin, $\mathrm{Phe}^{\mathrm{B} 1}$-citraconyl-BAP-insulin and BAP-insulin were collected. This procedure was repeated 10 times and the combined individual eluates were dialyzed against 11 of water (5 times) at

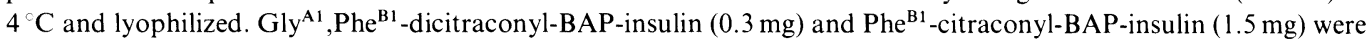
obtained along with BAP-insulin $(0.3 \mathrm{mg})$.

Preparation of Thiolated HRP (HRP-SH) _ A $250 \mu \mathrm{l}$ aliquot of $0.1 \mathrm{M} S$-acetylmercaptosuccinic anhydride in dimethylformamide was added to $5 \mathrm{mg}(125 \mathrm{nmol})$ of $\mathrm{HRP}$ in $2.5 \mathrm{ml}$ of $0.1 \mathrm{M} \mathrm{Na}$ phosphate buffer $(\mathrm{pH} 7.5)$ containing $0.1 \mathrm{M} \mathrm{NaCl}$ under stirring at $30^{\circ} \mathrm{C}$, and the mixture was stirred continuously for $1 \mathrm{~h}$. The resulting mixture was dialyzed against 11 of $0.1 \mathrm{M} \mathrm{Na}$ phosphate buffer ( $\mathrm{pH} 6.0$, evacuated) at $4{ }^{\circ} \mathrm{C}$. To the dialyzate $(2.7 \mathrm{ml}), 540 \mu \mathrm{l}$ of $0.1 \mathrm{M}$ Tris- $\mathrm{HCl}$ buffer ( $\mathrm{pH} \mathrm{7.0,} \mathrm{evacuated),} 54 \mu \mathrm{l}$ of $0.1 \mathrm{M}$ ethylenediaminetetra acetic acid (EDTA) $\cdot 2 \mathrm{Na}$ in the $\mathrm{Tris}-\mathrm{HCl}$ buffer and $190 \mu \mathrm{l}$ of $1 \mathrm{M}$ hydroxylamine $\cdot \mathrm{HCl}$ in the Tris- $\mathrm{HCl}$ buffer were added. Immediately after the addition, the $\mathrm{pH}$ of the solution was adjusted to 7.3 with $2.5 \mathrm{M} \mathrm{NaOH}$ (evacuated) at $30^{\circ} \mathrm{C}$ and the mixture was stirred continuously for $20 \mathrm{~min}$. The resulting mixture was dialyzed against 11 of $0.1 \mathrm{M} \mathrm{Na}$ phosphate buffer ( $\mathrm{pH} 6.0$ ) containing $0.05 \mathrm{M} \mathrm{NaCl}$ and $5 \mathrm{~mm}$ EDTA $2 \mathrm{Na}$ (evacuated) (4 times) at $4{ }^{\circ} \mathrm{C}$. A $3.5 \mathrm{ml}$ aliquot of HRP-SH solution $(35.7 \mathrm{nmol} / \mathrm{ml})$ was obtained. The number of sulfhydryl groups in the HRP-SH was determined as 2.15 by the $4,4^{\prime}-$ dithiodipyridine method. ${ }^{19)}$

Preparation of HRP-Insulin (1 : 1) Conjugate-BAP-insulin $(150 \mathrm{nmol}, 0.9 \mathrm{mg})$ was dissolved in $700 \mu \mathrm{l}$ of the HRP-SH solution (evacuated) and the $\mathrm{pH}$ of the mixture was adjusted to 8.0 with $2.5 \mathrm{M} \mathrm{NaOH}$ (evacuated) under stirring at $30^{\circ} \mathrm{C}$. The mixture was kept at $30^{\circ} \mathrm{C}$ for $1 \mathrm{~h}$. The resulting mixture was dialyzed against 11 of water $(3$ times) at $4 \mathrm{C}$ and lyophilized. The resulting powder was dissolved in $200 \mu \mathrm{l}$ of $0.1 \mathrm{M} \mathrm{Na}$ phosphate buffer (pH 7.0) and subjected to gel-permeation HPLC. The eluate from the peak of HRP-insulin was collected, and dialyzed against 11 of water $\left(2\right.$ times) at $4{ }^{\circ} \mathrm{C}$. The dialyzate was concentrated to $2.0 \mathrm{ml}(10.3 \mathrm{nmol} / \mathrm{ml} \mathrm{HRP}$-insulin conjugate $)$ under vacuum, and the solution was stored at $-20^{\circ} \mathrm{C}$. The molar ratio of HRP to insulin in the conjugate was estimated from the amino acid analysis data. The concentration of the HRP-insulin conjugate was calculated from the absorbance at $403 \mathrm{~nm}$, where the absorption is only due to the HRP moiety. The molar absorptivity of HRP at $403 \mathrm{~nm}$ was taken as $\left.1.02 \times 10^{5} \mathrm{M}^{-1} \mathrm{~cm}^{-1} .20\right)$

\section{Results and Discussion}

The $N$-succinimidyl ester moiety in the reagents undergoes nucleophilic attack by a primary amine to form an amide bond. ${ }^{21)}$ Because HRP and its derivatives have been widely used in biological investigations, the introduction of bromoacetamido- $n$-alkanoyl groups into HRP was examined.

Table II shows the number of bromoacetamido- $n$-alkanoyl groups introduced per HRP under the described conditions. The maximum number was 2.1-3.2. A similar result was observed in the introduction of the 3-(2-pyrydyldithio)propionoyl or $\varepsilon$-maleimidocaproyl group into HRP using SPDP or $N$-( $\left(\right.$-maleimidocaproyloxy)succinimide (EMCS), ${ }^{22)}$ re- 
TABLE II. Number of Bromoacetamido- $n$-alkanoyl Groups Introduced into HRP ${ }^{a}$

\begin{tabular}{cccccc}
\hline \hline & \multicolumn{5}{c}{ Reagent/HRP (mol/mol) in the reaction } \\
\cline { 2 - 6 } Reagent & 10 & 15 & 25 & 50 & 100 \\
\hline II(1) & 0.5 & 0.6 & 1.0 & 1.6 & 2.3 \\
II(2) & 0.8 & 1.1 & 1.5 & 1.8 & 2.1 \\
II(3) & 1.3 & 1.6 & 2.2 & 2.5 & 2.6 \\
II(4) & 1.2 & 1.8 & 2.3 & 2.9 & 3.2 \\
II(5) & 1.3 & 1.8 & 2.1 & 2.6 & 2.6 \\
\hline
\end{tabular}

a) Based on 23 residues of alanine in an HRP molecule.

TABLE III. Number of II $(n)$ Moieties Introduced into Lysozyme and RT-Lysozyme ${ }^{a)}$

\begin{tabular}{|c|c|c|c|c|c|c|}
\hline \multirow{2}{*}{ Reagent } & \multirow{2}{*}{$\begin{array}{c}\text { Lysozyme } \\
\text { or }\end{array}$} & \multicolumn{5}{|c|}{$\begin{array}{c}\text { Reagent/lysozyme or RT-lysozyme }(\mathrm{mol} / \mathrm{mol}) \\
\text { in the reaction }\end{array}$} \\
\hline & & 10 & 15 & 25 & 50 & 100 \\
\hline \multirow[t]{2}{*}{$\mathrm{II}(1)$} & L & 0.7 & 1.2 & 1.3 & 4.5 & 5.8 \\
\hline & RT-L & 1.2 & 1.6 & 2.7 & 6.0 & 7.6 \\
\hline \multirow[t]{2}{*}{$\mathrm{II}(2)$} & L & 5.5 & 6.8 & 7.7 & 8.1 & 10.9 \\
\hline & RT-L & 6.1 & 7.8 & 9.1 & 9.7 & 11.1 \\
\hline \multirow[t]{2}{*}{$\mathrm{II}(3)$} & L & 3.0 & 4.1 & 5.0 & 7.1 & 8.7 \\
\hline & RT-L & 4.0 & 5.0 & 7.3 & 8.5 & 9.6 \\
\hline \multirow[t]{2}{*}{ II(4) } & L & 3.4 & 4.5 & 5.1 & 6.4 & 7.9 \\
\hline & RT-L & 4.7 & 6.7 & 7.5 & 8.5 & 9.6 \\
\hline \multirow[t]{2}{*}{$\mathrm{II}(5)$} & $\mathrm{L}$ & 4.5 & 5.7 & 6.5 & 8.8 & 10.0 \\
\hline & RT-L & 6.4 & 8.1 & 8.7 & 9.9 & 10.5 \\
\hline
\end{tabular}

a) Based on 12 residues of alanine in a lysozyme molecule. b) L, lysozyme; RT-L, RT-lysozyme.

spectively (data not given). There is no evidence of alkylation of lysine or histidine residues of HRP, indicating that the reaction occurred only at the $N$-succinimidyl ester side of $\operatorname{II}(n)$. These observations suggest that $\mathrm{II}(n)$ can be used for controlled introduction of bromoacetamido- $n$-alkanoyl groups into protein amino groups.

The reactions of II $(n)$ with lysozyme and RT-lysozyme were also investigated (Table III). Lysozyme is useful to examine various reactions because the protein contains all the kinds of amino acid residues that occur in natural proteins. The number of $\mathrm{II}(n)$ moieties introduced into RT-lysozyme was greater than that for lysozyme. This can be explained on the basis of the unfolded structure of RT-lysozyme. The introduction of more than $7 \mathrm{II}(n)$ moieties was observed, though lysozyme and RT-lysozyme both have 7 amino groups. The reason for this result is not known.

In general, haloacyl groups readily react with the thiolate ion, and under certain conditions, they also react with other nucleophilic sites (amino, imidazole and thioether groups) of proteins. ${ }^{23)}$ Thus, II $(n)$ should be usable for cross-linking between a protein without a reactive sulfhydryl group and a protein with a reactive sulfhydryl group.

Because of our interest in the use of enzymelabeled insulin in an assay of insulin receptor, we prepared HRP-insulin conjugate by using II(2) (Chart 2). HRP was selectively linked to the $\varepsilon$-amino group of the lysine ${ }^{\mathrm{B} 29}$ residue of insulin. In the first step, a single BAP group was introduced into $\mathrm{Gly}^{\mathrm{A} 1}, \mathrm{Phe}^{\mathrm{B} 1}$-dicitraconyl-insulin to obtain $\mathrm{Gly}^{\mathrm{A} 1}$, $\mathrm{Phe}^{\mathrm{B} 1}$ dicitraconyl-BAP-insulin. Then, the citraconyl groups of $\mathrm{Gly}^{\mathrm{A} 1}, \mathrm{Phe}^{\mathrm{B} 1}$-dicitraconyl-BAP- 


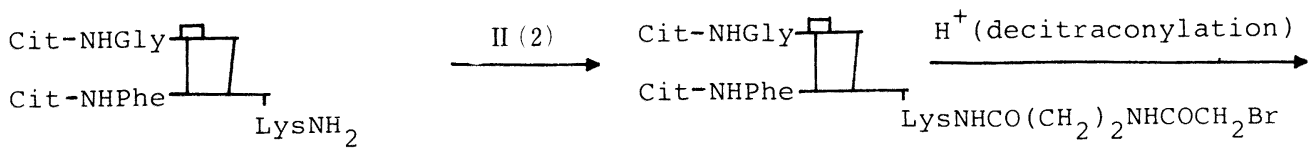

Gly $\mathrm{A}^{\mathrm{Al}}$, Phe $\mathrm{Bl}^{\mathrm{Bl}}$-dicitraconylinsulin $\quad \mathrm{Gly}^{\mathrm{Al}}$, $\mathrm{Phe}^{\mathrm{Bl}}$-dicitraconyl-BAP-insulin

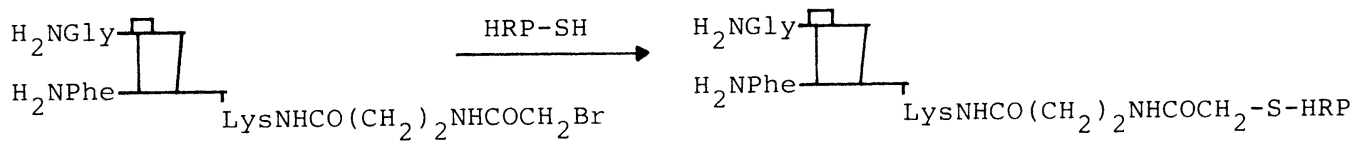

BAP-insulin

HRP-insulin conjugate

Chart 2. Introduction of a Single BAP Group into $\mathrm{Gly}^{\mathrm{A} 1}, \mathrm{Phe}^{\mathrm{B} 1}$-Dicitraconylinsulin and Preparation of HRP-Insulin Conjugate

Cit: citraconyl.

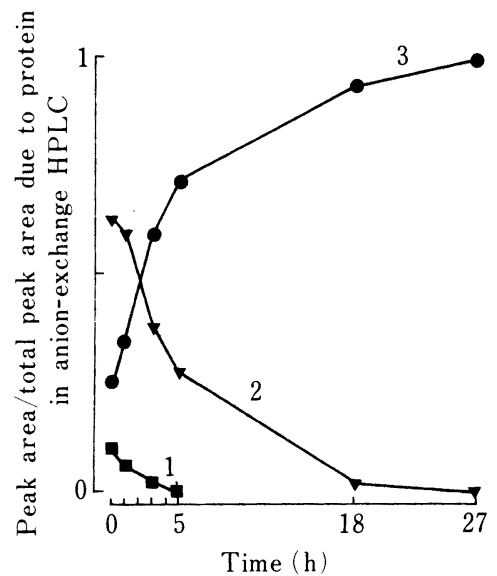

Fig. 1. Time-Course of Decitraconylation of Gly $^{\mathrm{A} 1}, \mathrm{Phe}^{\mathrm{B} 1}$-Dicitraconyl-BAP-Insulin and $\mathrm{Phe}^{\mathrm{B} 1}$-Citraconyl-BAP-Insulin

The dialyzate obtained after the reaction of II (2) with Gly ${ }^{\mathrm{A} 1}, \mathrm{Phe}^{\mathrm{B} 1}$-dicitraconylinsulin in the procedure for the preparation of BAP-insulin was allowed to stand at $30^{\circ} \mathrm{C}$ for various periods $(1-27 \mathrm{~h})$ in the presence of $1 \mathrm{M}$ acetic acid. Portions $(10 \mu \mathrm{l})$ of the dialyzate and the mixtures at various reaction periods were subjected to anion-exchange HPLC. Curves: 1, $\mathrm{Gly}^{\mathrm{A} 1}, \mathrm{Phe}^{\mathrm{B} 1}$-dicitraconyl-BAP-insulin; 2, $\mathrm{Phe}^{\mathrm{B} 1}$ citraconyl-BAP-insulin; 3, BAP-insulin.

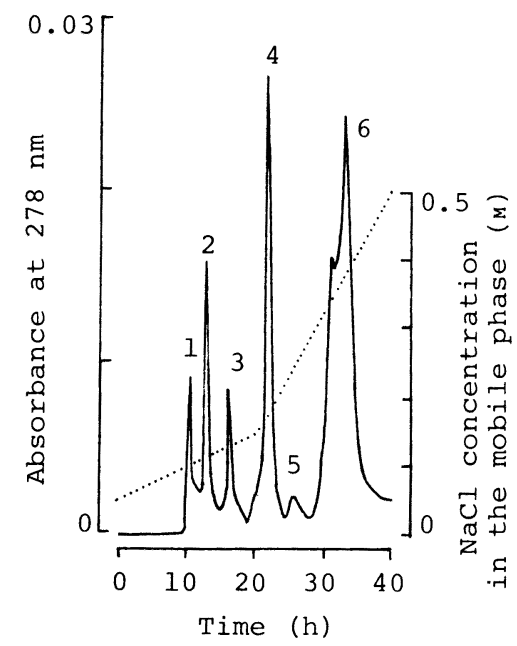

Fig. 2. Chromatogram of Insulin Derivatives

A portion $(60 \mu \mathrm{l})$ of the neutralized mixture obtained in the preparation of $\mathrm{Gly}^{\mathrm{A} 1}, \mathrm{Phe}^{\mathrm{B} 1}$-dicitraconyl$\mathrm{BAP}$-insulin and $\mathrm{Phe}^{\mathrm{B} 1}$-citraconyl-BAP-insulin was subjected to anion-exchange HPLC. Peaks: 1, insulin; 2, BAP-insulin; 3, citraconic acid; 4, $\mathrm{Phe}^{\mathrm{B1}}$-citraconylBAP-insulin; 5, Gly ${ }^{\mathbf{A} 1}, \mathrm{Phe}^{\mathrm{B} 1}$-dicitraconyl-BAP-insulin; 6, unknown (non-protein).

insulin were eliminated with $1 \mathrm{M}$ acetic acid to obtain BAP-insulin. The time-course of the decitraconylation could be followed by anion-exchange HPLC (Fig. 1). A chromatogram of the neutralized mixture obtained in the preparation of $\mathrm{Gly}^{\mathrm{A} 1}, \mathrm{Phe}^{\mathrm{B} 1}$-dicitraconyl-BAP-insulin and $\mathrm{Phe}^{\mathrm{B} 1}$-citraconyl-BAP-insulin is shown in Fig. 2. The decitraconylation had to be carried out prior to the conjugation with HRP, otherwise a marked deactivation of HRP was observed. The BAP group of the insulin was stable in the acidic medium. On the other hand, when EMCS was used instead of II(2), the $\varepsilon$-maleimidocaproyl group introduced into $\mathrm{Gly}^{\mathrm{A} 1}$,Phe ${ }^{\mathrm{B} 1}$-dicitraconylinsulin was destroyed by the acid treatment (data not given). These 
observations suggest that the acid-resistant-nature of the bromoacetyl group can be effectively employed in the course of preparation of protein conjugates.

The reaction of the HRP-SH with an approximately 6-fold molar excess of BAP-insulin gave HRP-insulin $(1: 1)$ conjugate. Excess BAP-insulin could be recovered easily by gelpermeation HPLC because the molecular size of BAP-insulin is much smaller than that of HRP-insulin conjugate. The molar ratio of HRP to insulin in the conjugate could be calculated as 1:1.01 from the results of amino acid analysis of the conjugate. In the calculation, the molar ratio of $\beta$-alanine to alanine in BAP-insulin $(1: 2)$ was used and the amount of alanine derived only from the HRP moiety of the conjugate could be estimated by using the amount of $\beta$-alanine. The principle of the method should be applicable for the estimation of the molar ratio of protein to protein in other protein-protein conjugates prepared with II $(n)$ except for II(1).

The HRP-insulin conjugate retained $66.7 \%$ of native HRP activity. The actual use of the conjugate will be described elsewhere.

Acknowledgements We wish to thank Miss N. Tohjyo for superb technical assistance, Messrs. M. Shido and M. Abe for elemental analysis and Mr. R. Isobe for MS measurement. We also wish to thank Drs. T. Imoto and H. Yamada for their helpful suggestions and Toyo Soda Manufacturing Co., Ltd. for the generous gift of HPLC columns.

\section{References and Notes}

1) F. Wold, Methods Enzymol., 28, 623 (1972).

2) K. Peters and F. M. Richards, Annu. Rev. Biochem., 46, 523 (1977).

3) J. Carlsson, H. Drevin, and R. Axen, Biochem. J., 173, 723 (1978).

4) M. Imagawa, S. Hashida, E. Ishikawa, and A. Sumiyoshi, J. Appl. Biochem., 4, 400 (1982).

5) K. Sugimoto, K. Zaitsu, and Y. Ohkura, Anal. Chim. Acta, 169, 133 (1985).

6) R. Fallon and A. Malcolm, Biochem. Soc. Trans., 13, 367 (1985).

7) R. L. Kincaid and M. Vaugham, Biochemistry, 22, 826 (1983).

8) A. Goundalkar, T. Ghose, and M. Mezei, J. Pharm. Pharmacol., 36, 465 (1983).

9) T. Kitagawa and T. Aikawa, J. Biochem. (Tokyo), 79, 233 (1976).

10) M. Ohnishi, H. Sugimoto, H. Yamada, T. Imoto, K. Zaitsu, and Y. Ohkura, Chem. Pharm. Bull., 33, 674 (1985).

11) M. Ohnishi, H. Sugimoto, H. Yamada, T. Imoto, K. Zaitsu, and Y. Ohkura; A report on the reagent II(2) was presented at the 103rd Annual Meeting of the Pharmaceutical Society of Japan, Tokyo, April 1983.

12) K. Okazaki, T. Imoto, and H. Yamada, Anal. Biochem., 145, 87 (1985).

13) K. Zaitsu, H. Hosoya, Y. Hayashi, H. Yamada, and Y. Ohkura, Chem. Pharm. Bull., 33, 1159 (1985).

14) K. Zaitsu and Y. Ohkura, Anal. Biochem., 109, 109 (1980).

15) D. D. Pless, S. Roseman, Y. C. Lee, and R. L. Schnaar, J. Biol. Chem., 258, 2340 (1983).

16) Y. Nakagawa and G. E. Perlmann, Arch. Biochem. Biophys., 149, 476 (1972).

17) The handling manual for the Hitachi 835 amino acid analyzer, No. 835-1978, Hitachi Co., Tokyo, Japan.

18) H. Yamada, F. Uozumi, A. Ishikawa, and T. Imoto, J. Biochem. (Tokyo), 95, 503 (1984).

19) D. R. Grassetti and J. F. Murray, Jr., Arch. Biochem. Biophys., 119, 41 (1967).

20) G. R. Schobaum and S. Lo, J. Biol. Chem., 247, 3353 (1972).

21) G. W. Anderson, J. E. Zimmerman, and F. M. Callahan, J. Am. Chem. Soc., 86, 1839 (1964).

22) O. Keller and J. Rudinger, Helv. Chim. Acta, 58, 531 (1975).

23) A. Fontana and C. Toniolo, "The Chemistry of the Thiol Group," part 1, ed. by S. Pattai, John Wiley and Sons, Inc., New York, 1974, pp. 271-324. 